\title{
Empowerment of Watermelon Farmer at Mojosari Village Puger District Jember in Producing Watermelon Low Pesticide Residue
}

\author{
Nanang Tri Haryadi*, Hari Purnomo, Titin Agustina
}

Department of Agrotechnology, Faculty of Agriculture, Jember University

Submitted: August 30 th 2018; Revised: June 30 th 2021; Accepted: August $11^{\text {th }} 2021$

Keywords:

Biological agents

Low residue

Watermelon

\begin{abstract}
Mojosari Village, Puger Sub-district, is the largest watermelon center in Jember Regency. In 2017, the total harvested area reached $900 \mathrm{Ha}$ and productivity reached $290.72 \mathrm{~kW} / \mathrm{Ha}$. The problem that often arises in watermelon cultivation is the attack of plant pests. Pests that often attack watermelons include caterpillars, whitefly, fruit flies, and thrips. Pest control that is often used by farmers is sprayed with chemical pesticides. The spraying of chemical pesticides began to be complained about by farmers because they were not able to control pests, this was probably because the pests were already resistant to pesticides. The decline in watermelon quality is also caused by soil conditions that have begun to decrease in nutrient content, due to the use of excessive chemical fertilizers. Farmers become dependent on chemical pesticides and chemical fertilizers in watermelon cultivation. Therefore, it is necessary to educate farmers to reduce the use of excessive chemical pesticides and fertilizers. One alternative is to use environmentally friendly biological control agents. The result of this activity is that farmers can reproduce biological agents, namely the fungus Metarhizium anisopliae, Beauveria bassiana, Trichoderma, entomopathogenic nematodes, and make organic fertilizers. Farmers can produce biological agents and apply them to watermelon fields. The resulting watermelon is more durable to store and does not rot easily after harvest.
\end{abstract}

\section{INTRODUCTION}

Watermelon is a plant that has long been cultivated and has become the main source of income for the people of Mojosari Village, Puger District, Jember Regency. Based on data from Statistic Jember Regency in 2017, the total harvested area reached $900 \mathrm{Ha}$, productivity reached $290.72 \mathrm{~kW} / \mathrm{Ha}$, production reached 261,650 kW (Statistic Jember Regency, 2018). Puger District is the center for watermelon plants because it has land that is very suitable for watermelon growth, namely sandy land, and close to the beach which has hot weather.

The problems that are often faced by farmers in watermelon cultivation in Mojosari Village, Puger District, which cause a decrease in watermelon production are the attack of plant pest organisms, such as leaf caterpillars (Spodoptera litura) and wilt disease caused by the fungus Fusarium oxysporum.
These problems became the background for the team conducting community services. This community service activity was carried out in Mojosari Village, Puger District, involving a combination of farmer groups as activity partners. Partners in this community service activity are a combination of farmer groups called GAPOKTAN in Mojosari Village, Puger District, which is chaired by Mr. Purwanto. Gapoktan in Mojosari consists of four farmer groups, namely Subur Jaya 1, Subur Jaya 2, Subur Jaya 3, and Subur Jaya 4. This farmer group was founded in 1998 and until now the average member is approximately 125 active members.

The control effort that has been carried out by farmers in Mojosari Village is by spraying chemical pesticides. Farmers generally use pesticides with active ingredients such as carbosulfan, propineb, abamectin, profenofos, difenoconazole, Diafentiuron, mancozeb,

ISSN 2460-9447 (print), ISSN 2541-5883 (online)

${ }^{*}$ Corresponding author : Nanang Tri Haryadi

Department of Agrotechnology, Faculty of Agriculture, Jember University, Jln. Kalimantan No. 37, Kampus Tegalboto, Jember, Jawa Timur 68121, Indonesia

Email: haryadint@gmail.com 
Deltamethrin, and imidacloprid. On average, farmers do spraying on a scheduled basis at intervals of once a week without prior monitoring of the pest and disease population in the field, so that the costs incurred for spraying are greater. On average, farmers spend $\mathrm{Rp} 1.500 .000,-/ \mathrm{Ha}$ in one growing season. The use of these chemical pesticides in 2016 tends to not show satisfactory results. The head of the Subur Jaya I farmer group in Mojosari Village said that from 2014-2018, the use of chemical pesticides at labeled doses was very effective in controlling pest and disease attacks, but now it is less effective. Farmers in Mojosari Village will generally increase the dose and frequency of spraying to make it effective. The ineffective use of chemical pesticides is due to the impact of the continuous use of chemical pesticides by farmers, resulting in the emergence of pest resistance (pests become resistant to the pesticides used). This condition causes farmers to tend to increase the dose to be more effective. This problem will give rise to the "pesticide treadmill", i.e. the use of chemical pesticides does not solve the problem, but will create an even bigger problem, then the farmer will increase the dose again and an even bigger problem will arise.

Another problem faced by the Subur Jaya II farmer group is the condition of the soil that is already saturated and the nutrient content is getting less and less. This condition is caused by the excessive and continuous use of chemical fertilizers. Excessive use of chemical fertilizers causes new problems, namely soil structure will be damaged, organic matter content decreases and causes environmental damage (Isnaini, 2006) and according to Rechcigl (1995), Excessive use of nitrogen $(\mathrm{N})$ fertilizers on plants results in many negative impacts such as excessive vegetative growth. This leads to excessive consumption of nitrogen and the fragility of plant tissues. Physiologically there is a decrease in sugar levels, slowing of plant maturity so that plants become very susceptible to disease and pest attacks. Another impact is that plants tend to be susceptible to disease, especially wilt and diseases caused by viruses. The indirect impact of the use of pesticides and chemical fertilizers is that it makes farmers very dependent on these materials and does not make farmers independent. When the price of fertilizers and pesticides rises, farmers cannot buy or look for other alternatives, resulting in lower production.

The problem of dependence on these chemicals will have an impact on the appearance of pesticide treadmills. This problem can lead to more serious problems in the long run if precautions are not taken to reduce chemicals. Improper efforts to increase watermelon production, with a high level of dependence on chemicals, have a continuing negative impact on human health value stakes due to chemical residues left behind. Therefore, through this Science and Technology for Society activity, it is necessary to educate and pilot farmers to reduce the excessive use of pesticides and chemical fertilizers. One alternative is to use control techniques that are more environmentally friendly and do not cause farmers' dependence on chemicals, namely using biological control agents that have been proven to be able to control plant pests and improve soil fertility. According to Islam et al., (2009), the use of biological agents such as fungi Beauveria bassiana with a concentration of 10 conidia $^{8} / \mathrm{ml}$ can cause mortality of infestation Bemisia tabaci reached $73 \%$. According to Zafar et al., (2016), the use of $B$. bassiana at a concentration of $2.4 \times 10^{7}$ was very effective in controlling pests $B$. tabaci with a mortality rate of eggs $(65.30 \%)$ and nymphs (88.82\%). Trichoderma sp. has been reported to be able to suppress fusarium disease which causes wilting of chili plants by $94 \%$ in vitro (Mukarlina et al., 2010).

At this time in the Department of Plant Protection, Faculty of Agriculture, University of Jember, has had several collections of biological control agents from the results of research conducted by a research group at the biological control laboratory that can be used to control pests and diseases in watermelon. Biological agents that have been developed at the Biological Contro Laboratory include Beauveria bassiana (Hari Purnomo collection), Metarhizium anisopliae (Nanang Tri Haryadi collection), Entomopathogenic nematodes (EPN) (Hari Purnomo \& Nanang Tri Haryadi collection), Trichoderma sp. and caterpillar predators Rhynocoris fuscipes (Hari Purnomo and Nanang Tri Haryadi collection). The entomopathogenic fungi from 2012 to 2014, has carried out a development study in the form of a granular formulation. Therefore, through this community service, farmers are given training and pilots on how to multiply and apply in the field in controlling pests and diseases of watermelon.

Based on the results of research by Purnomo and Haryadi (2012), it is known that the granular formulation of the fungus $B$. bassiana is very effective in controlling pests of the Order Coleoptera such as the coffee berry borer. This fungus has also been reported to be effective in controlling Aphids, Thrips, whiteflies, and caterpillars. The results of research by Haryadi et al., (2014), showed that the fungus M. anisopliae was also proven to be effective in controlling pests that attack plant roots such as earthworms. The use of Entomopathogenic nematodes was also proven to be effective in controlling caterpillar pests, while the application of the antagonistic fungus Trichoderma to the soil was able to inhibit the growth of wilt diseases such as fusarium wilt and bacterial wilt.

The biological control agents mentioned above are easy to propagate on a farmer scale, do not require special skills, and do not require expensive equipment, but the problem is that farmers in Mojosari Village, 
Puger District do not yet know how to reproduce and apply them to overcome pest problems in watermelon plants. Therefore, through this community service activity, the proposal team will provide mentoring, counselling, training, and piloting in a structured manner to partners to multiply biological control agents in the hope that farmers will no longer depend on chemicals.

Another alternative, in addition to using these biological control agents, is to use botanical pesticides whose raw materials are widely found in partner areas such as neem leaves, mahogany, and abundant tobacco waste. The use of neem and mahogany leaves has also been shown to be able to cause mortality in caterpillars and aphids. The use of biological control agents in pest control is the answer to the problems that can be caused by the widespread use of synthetic insecticides that have a negative impact. The advantages obtained by using biological control agents are: (1) environmentally friendly, (2) is a preventive control in the long term (long term strategies), (3) there is no additional input cost when the natural enemy is well established in the area.

The purpose of this community service is to provide guidance and education to partners to reduce the frequency of using chemicals such as synthetic pesticides and chemical fertilizers. The target of this community service activity is (a) partners can apply watermelon disease pest control technology that is environmentally friendly and able to produce its biological agents, making vegetable pesticides and organic fertilizers; (b) Partners become pilot locations for the application of environmentally friendly watermelon disease pest control technology.

\section{METHOD}

Implementation methods carried out by partner coaching include training in monitoring pest and disease populations, training in multiplying biological agents such as insect pathogenic fungi, entomopathogenic nematodes, and antagonistic fungi, and training in making organic fertilizers. The following are the stages of activities carried out on partners:

1. Providing counseling and pilot in a structured manner on pest monitoring techniques of diseases that attack watermelon. This activity is carried out using hands-on practice in the field on how to calculate the pest population of the disease. The ability to monitor pests and diseases as the basis for taking control measures. Monitoring activities can reduce the frequency of pesticide spraying so that the cost of control is less if spraying on a scheduled basis.

2. Conducting counseling on important pests and diseases in watermelon, symptoms of attack as well as the biology of the pest of the disease. This activity is carried out by providing counseling by showing pictures and symptoms of pests and diseases that often attack watermelon plants. This activity is expected to allow farmers to distinguish between pests and natural enemies, and be able to distinguish the symptoms of fungal and bacterial attacks.

3. Conducting structured training on how to make and multiply biological agents with entomopathogenic fungi active ingredients such as Beauveria bassiana and Metarhizium anisopliae. The activity is carried out by the practice of producing biological agents, then conducting a demo plot of entomopathogenic fungi spraying produced on farmers' land, then continued with observations of the effect of the application of biological agents to pest populations. Farmers are invited to observe in the field the symptoms of pests infected by fungi.

4. Trichoderma mass-production practice to protect against withering diseases that attack watermelon.

5. The practice of producing entomopathogenic nematodes (EPN) to protect caterpillar pests that attack watermelons. Farmers will be trained to isolate EPN from the soils in Mojosari Village to obtain location-specific EPN isolates, so it is expected that it will have a better level of pathogenicity.

6. Conducting structured training and practice of making organic fertilizer with raw materials of animal manure that is widely found in Mojosari Village, because most farmers have cows.

The success of this program can be seen by using several indicators such as in Table 1.

Table 1. Indicators of activity success

\begin{tabular}{lll}
\hline Activity components & Before The Activity & After The Activity \\
\hline Monitoring techniques & $\begin{array}{l}\text { Farmers have not done pest and disease } \\
\text { monitoring }\end{array}$ & $\begin{array}{l}\text { Farmers can monitor pests and diseases of } \\
\text { watermelon }\end{array}$ \\
\hline Pest Counselling Watermelon disease & $\begin{array}{l}\text { Farmers have not been able to distinguish } \\
\text { between pests and natural enemies of } \\
\text { watermelon }\end{array}$ & $\begin{array}{l}\text { Farmers can distinguish pests and natural } \\
\text { enemies of watermelon }\end{array}$ \\
\hline Production of entomopathogenic fungi & Unable to produce entomopathogenic fungi & Able to produce entomopathogenic fungi \\
\hline $\begin{array}{l}\text { Production of entomopathogenic } \\
\text { nematodes }\end{array}$ & $\begin{array}{l}\text { Unable to produce entomopathogenic } \\
\text { nematodes }\end{array}$ & $\begin{array}{l}\text { Farmer can produce entomopathogenic } \\
\text { nematodes }\end{array}$ \\
\hline Organic fertilizer production & $\begin{array}{l}\text { Farmers have not been able to produce organic } \\
\text { fertilizer }\end{array}$ & Farmers can produce organic fertilizer \\
\hline
\end{tabular}




\section{RESULT AND DISCUSSION}

\subsection{Identification of watermelon pests in the field}

This activity was carried out to introduce directly to farmers the dominant pests that attack watermelon plants (Figure 1). This activity begins with the provision of material about pests and diseases that often attack watermelon plants before seeing them directly in the field. Farmers are shown pictures via LCD projectors and have discussions before going into the field to get to know more about watermelon pests.

From the results of the discussion of this activity, it is known that farmers are still unable to distinguish between pests and diseases of watermelon plants. Farmers also do not know the reason why the plants do not grow normally. For example, farmers do not know the cause of curly leaves, yellowing leaves, and rotten fruit. The results of field visits showed that the dominant pests were whitefly, Aphid, and Thrip, while the dominant diseases were wilting, leaf curl, and fruit rot.

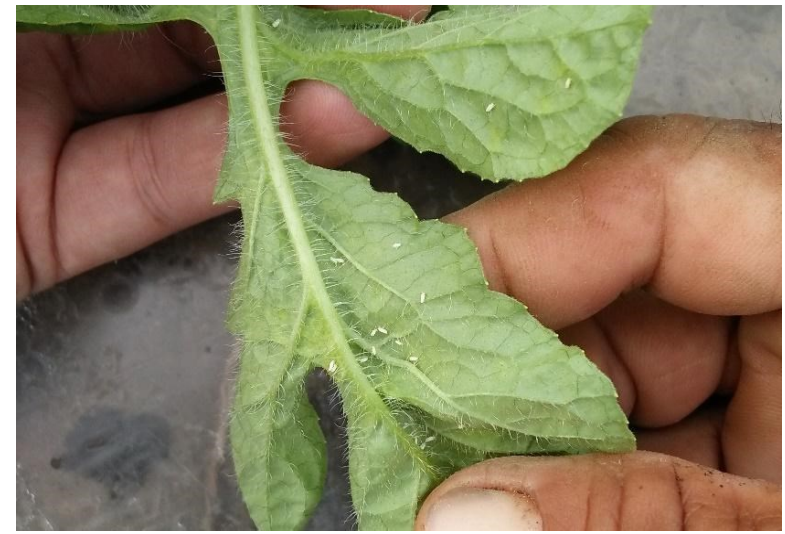

Figure 1. Observation of pests in field and Bemisia tabaci attacking watermelons

\subsection{Training on the production of entomopathogenic fungi and antagonistic fungi}

This activity aims to introduce farmers to some biological agents that can be used to control pests and diseases that attack watermelon. Biological agents introduced to farmers namely Beauveria bassiana, Metarhizium sp., Trichoderma sp.. Farmers are trained in how to mass production the fungi on a farmer scale (Figure 2)

Production of mushrooms B. bassiana, Metarhizium sp. and Trichoderma sp. can be done by preparing ingredients namely corn rice, sterile water, isolate mushrooms, and plastic. Tools used include a corn rice steamer. The manufacturing stage starts with washing the corn rice thoroughly, then steaming the corn rice for 45 minutes or half-cooked. Cooked corn rice is then chilled on a tray. The next step is to put corn rice in a plastic bag of as much as $100 \mathrm{~g}$ of rice/corn, then sterilized by using a boiler for approximately 60 minutes. The next step is to prepare isolates by pouring sterile water in a test tube containing fungi and then shaking, the solution is then taken using a syringe and then injected in the rice or corn medium. The corn media that has been inoculated with fungi is then covered with staples. The plastic is then arranged in a container using a clean and dry indoor. The fungus is then incubated for 7 days. B. bassiana will grow white, while M. anisopliae and Trichoderma will grow green.

\subsection{Training on the production of} Entomopathogenic fungi with Liquid Media

Entomopathogenic fungi propagation activities were also carried out using liquid media and propagated using a simple fermenter. The use of liquid media aims to be more practical in the application of biological agents such as for spraying and dispensing. The medium used for propagation with this liquid medium is coconut water. Propagation of entomopathogenic fungi can be done by preparing materials such as fungal isolates, coconut water media, filters, and $\mathrm{KMnO} 4$. The tools used are aerators and plastic hoses. The next step is to insert $\mathrm{KMnO} 4$ solution, filter, and distilled water into a plastic bottle. The next step is to put coconut water in the fermenter and inoculate it with biological agent fungi. The next step connects the aerator with the container containing $\mathrm{KMnO} 4$, filter bottle, fermenter, and a bottle containing distilled water as shown in Figure 3.

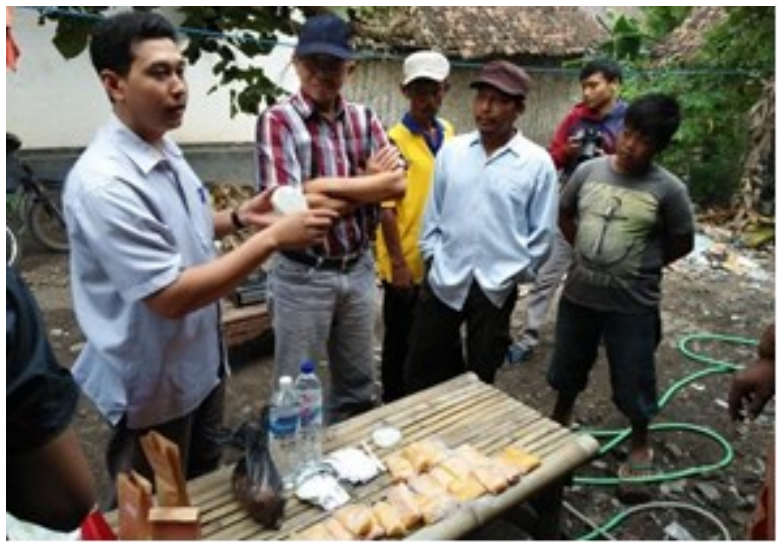

Figure 2. Mass production entomopathogenic fungi

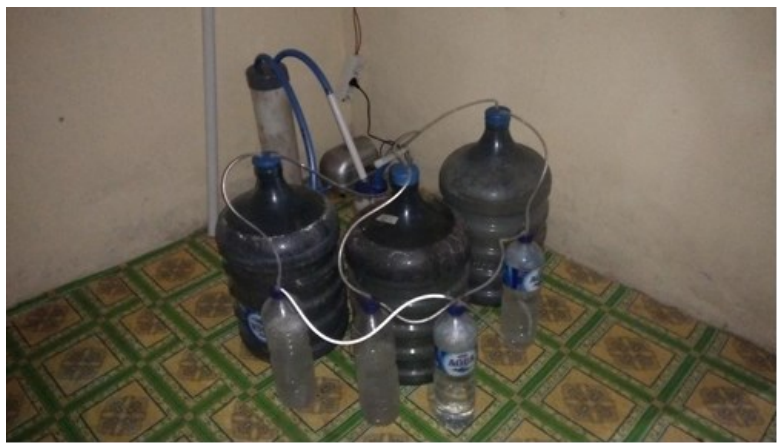

Figure 3. Production of Beauveria bassiana using liquid media 3.4. Training on the Propagation of Entomopathogenic Nematodes

This training activity aims to train farmers to produce entomopathogenic nematodes (Figure 4). The 
first stage is to train farmers to isolate nematodes from fields, this is done to find out whether the land owned by farmers is found to have a lot of nematodes. At this stage, the soil that has been taken is then put in a plastic cup then filled with Tenebrio molitor, then when the soil is watered and left for 3 days stored in a dark. The dead T. molitor is then carried out with a white trap, by arranging the $T$. molitor in a plastic container that has been lined with tissue, then the container is placed in a large container that has been given water. After 4 days, the water in a large container is ready to be harvested and applied in the field.

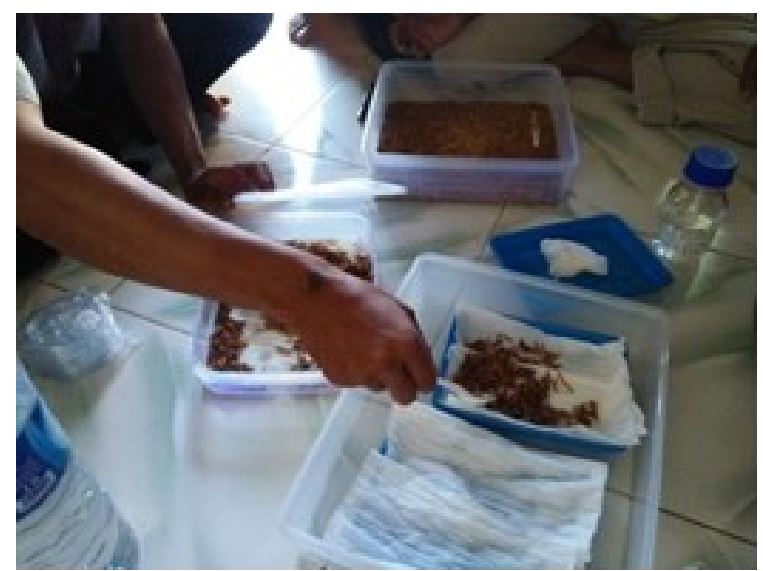

Figure 4. Entomopathogenic nematodes propagation training

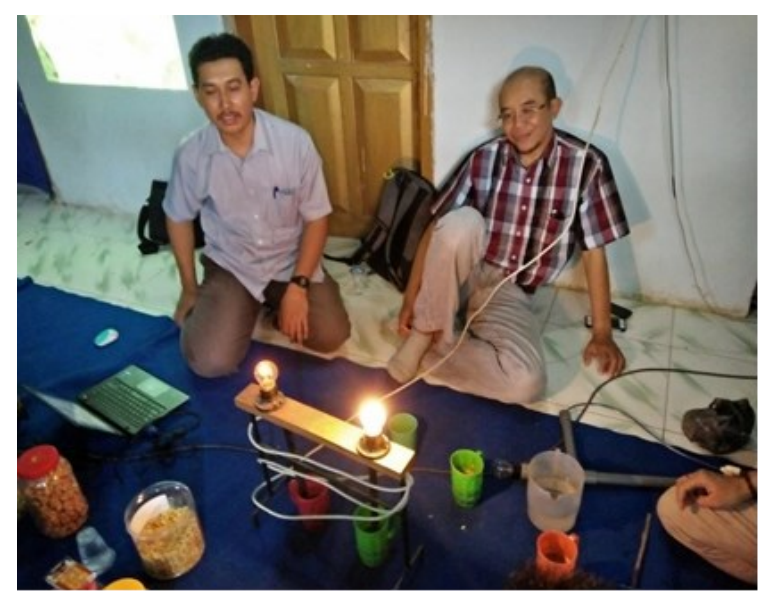

Figure 5. Introduction to detecting soil organic matter content

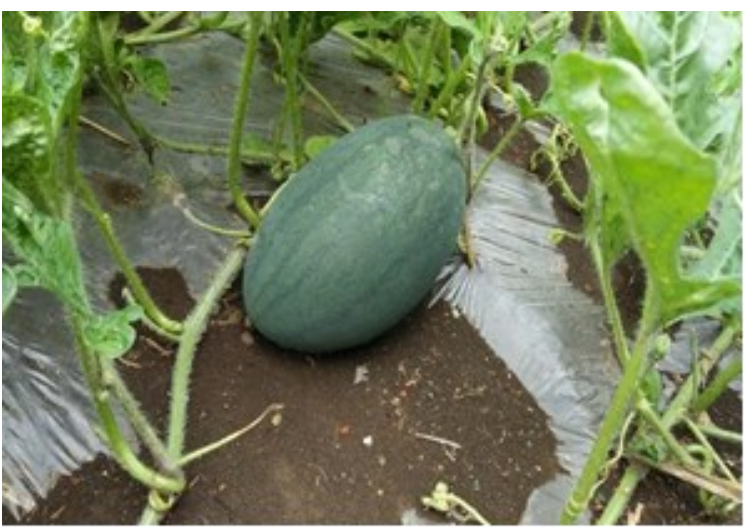

Figure 6. Harvest of watermelon from the demo plot

\subsection{Soil Fertility Test Farmers Using Simple Tools}

This activity aims to determine the fertility rate of farmers' land, which is often given chemical fertilizers. Farmers often give excessive chemical fertilizers to their land but the production has not been as expected. To know the soil fertility rate is not easy, can not be done only by touch and seen, but must be done with soil fertility tests in the laboratory at a cost and not all farmers have access to perform fertility tests of the soil. Therefore, farmers were introduced to how to detect soil fertility using a simple tool that uses electrical circuits and lamps (Figure 5). Soil fertility is closely related to the organic content of the soil. The more organic matter contained in the soil, the more fertile it will be.

As we all know, plants need essential nutrients to sustain their life. These elements include; Nitrogen (N), Phosphorus (P), Potassium (K), Carbon (C), Magnesium (Mg), Calcium (Ca), Sulphur (S), zinc (Fe), and other elements. It turns out that the substances needed by these plants are mostly electrolyte solutions. An indicator of fertile soil that contains a lot of organic matter, i.e. the light will light up brighter than the soil that contains less organic matter. The test results show that the soils in Mojosari on average have a low fertility level, with the indicator lights turning on dimmer when compared to soils with a lot of organic matter.

\subsection{Demonstration Of Application Of Biological Agents In Watermelon Plantations}

Application of biological agents is applied on farmers' land to control pests that attack watermelons. Pests that are found include leaf-sucking pests. Application of Trichoderma sp. done after soil processing, and simultaneously with the application of organic fertilizer. The application of entomopathogenic fungi such as B. bassiana and Metarhizium sp. was carried out at the time of the discovery of pest populations that had begun to increase. Application Trichoderma sp. can be done by pouring on the soil or mixing mushrooms with soil. The application dose of entomopathogenic fungi is 50 grams $B$. bassiana or M.anisopliae for 1 sprayer tank size 14 litters. The way of application is done by weighing 50 grams of entomopathogenic fungi then put in a bucket containing clean water approximately 14 litters, then the media is kneaded slowly until the fungus detaches from the media, then put the solution in a sprayer tank with filtered so as not to clog the sprayer nozzles.

Use of entomopathogenic fungi and fungi antagonists Trichoderma sp. help reduce pesticide use. According to farmers, watermelon produced from the application using organic ingredients, not easily rotten and has a different taste compared to watermelon applied pesticides (Figure 6). 


\section{CONCLUSION}

Based on the results of the utilization of biological control agents in watermelon cultivation in Mojosari Village, it can be concluded several things that farmers can monitor pests and diseases in watermelon crops and Bemisia tabaci as the dominant pest attacking watermelon crops, farmers can propagation biological control agents such as Beauveria bassiana, Trichoderma sp, Metarhizium anisopliae; and entomopathogenic nematodes.

\section{ACKNOWLEDGMENT}

Thank you to the Directorate of Research and Community Service of the Ministry of Research, Technology and Higher Education who has funded community service, the Subur Jaya Farmers Group, Mojosari Village, Puger District.

\section{REFERENCES}

BPS Kabupaten Jember. 2018. Kabupaten Jember dalam Angka. BPS Kabupaten Jember

Haryadi, N.T. W. Jadmiko, S. Hasjim. 2014. Integrasi Aplikasi Metarhizium Anisopliae Dan Nematoda Patogen Serangga Sebagai Agen Pengendali Hayati Hama Uret Lepidiota Stigma Yang Menyerang Tanaman Tebu. Laporan Penelitian.Universitas Jember. Tidak dipublikasikan.

Islam, T.Md, S.J. Castle. S. Ren. 2009. Compatibility of the insect pathogenic fungus Beauveria bassiana with neem against sweet potato whitefly, Bemisia tabaci, on eggplant. Entomologia Experimentalis et Applicata 134: 28-34. DOI: 10.1111/j.1570-7458.2009.00933.x.

Isnaini, M. 2006. Pertanian Organik. Kreasi Wacana. Yogyakarta. Hal 247-248.

Mukarlina, S. Khotimah, R.Rianti. 2010. Uji Antagonis Trichoderma harzianum Terhadap Fusarium spp. Penyebab Penyakit Layu pada Tanaman Cabai (Capsicum annum) Secara In Vitro. Jur. Fitomedika. Vol. 7. No.2.

Purnomo, H dan N.T Haryadi. 2012. Formulasi granuler biopestisida berbahan aktif Beauveria bassiana untuk pengendalian OPT Perkebunan. Laporan penelitian. Universitas Jember. Tidak dipublikasikan.

Purnomo, H dan N.T Haryadi. 2012. Uji lapang dan Laboratorium hasil formulasi granulasi Nematoda Entomopatogen (NEP). Laporan penelitian. Universitas Jember. Tidak dipublikasikan.

Rechcigl, J.E. 1995. Agriculture and Environment Series: Soil Amendments and Environmental Quality. CRC Press, 1st edition. The USA.

Zafar, J., S. Freed, B.A. Khan dan M. Farooq. 2016. Effectiveness of Beauveria bassiana Against Cotton Whitefly, Bemisia tabaci (Gennadius) (Aleyrodidae: Homoptera) on Different Host Plants. Pakistan J. Zool., vol. 48(1), pp. 91-99, 2016 